University of Nebraska - Lincoln

DigitalCommons@University of Nebraska - Lincoln

USDA National Wildlife Research Center - Staff Publications
U.S. Department of Agriculture: Animal and Plant Health Inspection Service

March 2001

\title{
Great Egret Preference for Catfish Size Classes
}

Scott J. Werner

USDA-APHIS-Wildlife Services, scott.j.werner@aphis.usda.gov

Mark E. Tobin

United States Department of Agriculture, Animal and Plant Health Inspection Service Wildlife Services, National Wildlife Research Center

Paul B. Fioranelli

United States Department of Agriculture, Animal and Plant Health Inspection Service Wildlife Services, National Wildlife Research Center

Follow this and additional works at: https://digitalcommons.unl.edu/icwdm_usdanwrc

Part of the Environmental Sciences Commons

Werner, Scott J.; Tobin, Mark E.; and Fioranelli, Paul B., "Great Egret Preference for Catfish Size Classes" (2001). USDA National Wildlife Research Center - Staff Publications. 575.

https://digitalcommons.unl.edu/icwdm_usdanwrc/575

This Article is brought to you for free and open access by the U.S. Department of Agriculture: Animal and Plant Health Inspection Service at DigitalCommons@University of Nebraska - Lincoln. It has been accepted for inclusion in USDA National Wildlife Research Center - Staff Publications by an authorized administrator of DigitalCommons@University of Nebraska - Lincoln. 


\title{
Great Egret Preference for Catfish Size Classes
}

\author{
SCOTt J. Werner ${ }^{1,3}$, MARK E. TOBIN ${ }^{2}$ AND PAUl B. Fioranelli ${ }^{1}$ \\ ${ }^{1}$ United States Department of Agriculture, Animal and Plant Health Inspection Service \\ Wildlife Services, National Wildlife Research Center \\ Mississippi Research Station, P.O. Drawer 6099, Mississippi State University, MS 39762 \\ ${ }^{2}$ United States Department of Agriculture, Animal and Plant Health Inspection Service \\ Wildlife Services, National Wildlife Research Center, 4101 LaPorte Avenue, Fort Collins, CO 80521 \\ ${ }^{3}$ E-mail: Scott.J.Werner@aphis.usda.gov
}

\begin{abstract}
Several species of fish-eating birds are commonly observed near aquaculture facilities in the southern United States. An understanding of the relationships between these birds and specific commodities is needed to interpret and manage bird impacts to aquacultural production. We conducted two foraging experiments to evaluate the preference of Great Egrets (Ardea alba) for three specific size classes of Channel Catfish (Ictalurus punctatus). During six no-choice feeding trials, egrets consumed significantly more small $(7.5-10 \mathrm{~cm})$ fingerlings than medium (15$18 \mathrm{~cm}$ ) or large $(23-25 \mathrm{~cm})$ catfish. Egrets captured 19 large catfish, and ingested only two, even when no other fish were available. During two-choice trials, Great Egrets significantly preferred small fingerlings to medium-sized fish, and medium-sized catfish to large fish. Handling time was directly related to the size of catfish ingested. Handling time was inversely related to the number of catfish ingested from each size class, particularly when Great Egrets were given a choice between two catfish size classes. Thus, we infer that the ease of capture and physical defenses (e.g., catfish spines) associated with particular foods affect Great Egret foraging preferences. Management of Great Egret impacts to aquacultural production should focus on dispersing egrets from ponds containing small $(<18 \mathrm{~cm})$ Channel Catfish, rather than generalized dispersal at all ponds on all farms. Received 1 October 2000, accepted 18 April 2001.

Key words.-Ardea alba, aquaculture, behavior, depredation, ecology, fish, foraging, handling time, Ictalurus punctatus, wading bird.
\end{abstract}

Waterbirds 24(3): 381-385, 2001

The commercial production of freshwater fish (i.e., aquaculture) in the southern United States is the fastest growing agricultural enterprise in the country. Southern aquaculture primarily involves about 100,000 ha of finfish (e.g., Channel Catfish [Ittalurus punctatus], particularly in Mississippi, Arkansas, Alabama, and Louisiana; bait fish [Carassius and Notropis spp.], especially in Arkansas; and shellfish (e.g., crawfish [Procambarus spp.], especially in Louisiana) and salmonid production [Salmo and Oncorhynchus spp.]). Several species of fish-eating birds (e.g., Double-crested Cormorants [Phalacrocorax auritus], American White Pelicans [Pelecanus erythrorhynchos], Great Blue Herons [Ardea herodias], Great Egrets [Ardea alba]) are commonly observed at or near aquaculture facilities. An understanding regarding the foraging preferences of these birds is needed to assess their relative impact to fisheries production and possible alternatives for managing such impacts.

Previous research has investigated wading bird food habits (Miranda and Collazo
1997; Young 1998) and their potential effects on aquacultural production (Avery et al. 1999; Glahn et al. 1999; Hoy 1994; King and LeBlanc 1995). However, few studies (including no captive experiments) have examined the preference of egrets for various sizes of fish (see Ross 1994; Willard 1977). We conducted this study to determine the preference of Great Egrets for three size classes of Channel Catfish. If Great Egrets prefer particular sizes of fish, then catfish farmers might be able to concentrate their management efforts on ponds containing such preferred size classes.

\section{METHODS}

\section{Captures and Foraging Experiments}

We used modified, soft-catch foothold traps (King et al. 1998) to live capture three Great Egrets in the delta region of western Mississippi. All captures were conducted in accordance with a current, Mississippi scientific collecting permit. We transported birds to the Mississippi Field Station of the National Wildlife Research Center, and weighed, banded, and inspected them for general health. Birds were maintained in individual outdoor cages $(2.4 \mathrm{~m} \times 1.2 \mathrm{~m} \times 1.2 \mathrm{~m})$ for at least 
seven days (i.e., acclimation period) before they were released into adjacent, 0.18 ha flight pens (one egret in each of three pens). Egrets acclimated in these pens for at least seven additional days before testing. During this acclimation period, each bird was offered live catfish (7$25 \mathrm{~cm}$, ad libitum $)$ in two plastic wading pools $(20 \times 100$ $\mathrm{cm})$. Fish were restocked daily based on consumption.

Each of two foraging experiments consisted of six foraging trials (2.5 hours per trial). All trials were conducted within five hours after sunrise on consecutive days. Each bird was offered live catfish in both wading pools during each foraging trial. Following each trial, egrets were again offered catfish $(7-25 \mathrm{~cm}$, ad libitum $)$ in two plastic wading pools until $17.00 \mathrm{~h}$, when access to food was deprived until the next morning's foraging trial. Foraging behavior was monitored from a 5-m high observation tower on the west side of the flight pens. An observer used binoculars, a spotting scope, and a stopwatch, clock, and tape recorder to measure and record the frequency of successful and unsuccessful foraging attempts at fish within pools. The handling time was recorded (to the nearest second) for each fish captured during the first hour of each foraging trial. The fate (i.e., ingested or dropped) of each captured catfish was also recorded for subsequent analyses.

The first foraging experiment evaluated the abundance of small, medium, and large catfish consumed when only one size class was offered during each trial. This experiment consisted of six trials during which each egret was offered each of three size classes of catfish (two replicate trials; one size class per trial). These length classes were $7.5-10 \mathrm{~cm}$ (small, average weight $=$ $4.9 \pm 0.02 \mathrm{~g} ; \mathrm{N}=30$ ), $15-18 \mathrm{~cm}$ (medium, average weight $=26.7 \pm 0.26 \mathrm{~g} ; \mathrm{N}=30$ ), and $23-25 \mathrm{~cm}$ (large, average weight $=84.2 \pm 0.94 \mathrm{~g} ; \mathrm{N}=30$ ). The number of fish in each pool was balanced based on biomass. The size class offered during the first trial was randomly determined so that each of the three egrets was offered a different size class. The size class offered during the second foraging trial was similarly determined so that each bird was offered a class different than that offered during the first trial. Each bird was offered the remaining size class during the third trial and the pattern of presentation was repeated during trials 4-6 for each egret.

The second foraging experiment evaluated egret preference for three catfish size classes. This experiment consisted of two replicates of three, two-choice foraging trials (i.e., six foraging trials with the following size-class pairs: $7.5-10$ and $15-18 \mathrm{~cm}$ (small-medium), 7.5-10 and 23-25 cm (small-large), and 15-18 and 23-25 $\mathrm{cm}$ (medium-large). The size-class combination was randomized so that (1) the three birds were offered a unique combination each trial during the first and last three trials, and (2) each bird was offered each combination on two occasions.

\section{Statistical Analyses}

The randomized block designs of both foraging experiments were analyzed using the general linear model procedure (PROC GLM) of the Statistical Analysis System (SAS 1989). The dependent measure for both studies was the number (i.e., abundance) of catfish consumed during foraging trials. For the first (no-choice) foraging experiment, factors were birds (i.e., blocks; error = bird-by-trial interaction), trials (i.e., offering each size class to each bird during two replicate trials), size classes $(7.5-10,15-18$, and $23-25 \mathrm{~cm}$ fish), and the trial-by-size class interaction (to assess possible learning effects through the study). The factors of the second (two-choice) foraging experiment were birds (error = bird-by-trial interaction), trials, treatments (each twoway combination of size classes; d.f. $=2$ ), size classes, and the trial-by-size class interaction. This interaction was used to analyze differences in egret preference for various size classes during two consecutive foraging trials.

Differences in handling times among catfish size classes were similarly analyzed using a randomized block design and PROC GLM. The handling time models considered the size classes and fate (ingested or dropped) of all catfish captured during foraging trials. The size class-by-fate interaction was analyzed for handling time differences in both foraging experiments. Tukey's post-hoc contrasts were used to separate the means of all significant ANOVA effects. We considered standard error (SE) as the measurement of variance about each of these means.

\section{RESULTS}

\section{No-choice Experiment: Size-specific Foraging}

The number of catfish consumed by egrets differed among size classes $\left(\mathrm{P}<0.001, \mathrm{~F}_{2,8}=\right.$ 29.91) when one size class was available during trials. The number of small catfish consumed was greater than the number of larger fish (15-18 and $23-25 \mathrm{~cm})$ that were consumed during this experiment (Tukey $\mathrm{P}<$ 0.05 ; Fig. 1). Only two large catfish were consumed during this experiment. No significant differences among birds $\left(\mathrm{F}_{2,8}=0.17\right)$, between trials $\left(F_{1,8}=0.54\right)$, or in a trial-by-size class interaction $\left(\mathrm{F}_{2,8}=0.74\right)$ were observed.

The average handling time associated with each catfish size class also differed in this experiment $\left(\mathrm{P}<0.001, \mathrm{~F}_{2,168}=18.58\right)$. Egrets handled medium-sized catfish for more time than large fish, and large catfish were handled longer than small fish $(\mathrm{P}<$ 0.05; Fig. 1). Egrets captured and dropped twice as many catfish as those that were ingested, and more time was spent handling fish that were ingested (relative to fish that were captured and dropped) in this experiment ( $\mathrm{P}<0.05$; Fig. 2a). A size class-by-fate interaction was also observed $\left(\mathrm{P}<0.001, \mathrm{~F}_{2,168}=\right.$ 9.02). Considering this interaction, the average handling time for catfish that were ingested was greatest for large fish, and the handling time for medium-sized fish was longer than that for small fish $(\mathrm{P}<0.05)$. The average handling time for catfish that were captured and dropped was greatest for large 

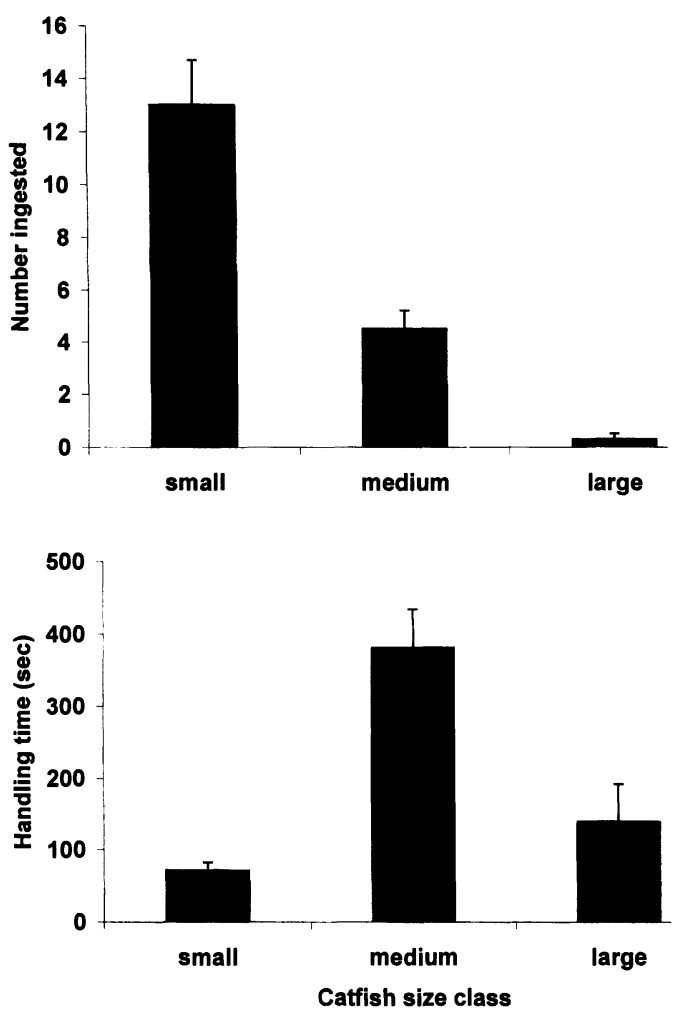

Figure 1. Mean $( \pm \mathrm{SE})$ number of small $(7.5-10 \mathrm{~cm})$, medium $(15-18 \mathrm{~cm})$, and large $(23-25 \mathrm{~cm})$ Channel Catfish consumed by 3 captive Great Egrets when offered one size class (no-choice) during two replicate foraging trials with each size class. The lower half of this figure illustrates the average time $( \pm S E)$ that 3 Great Egrets handled catfish during this experiment.

fish $(\mathrm{P}<0.05)$, but did not differ between medium-sized fish and small fish $(\mathrm{P}>0.05)$.

\section{Two-choice Experiment: Size Preference}

During the second foraging experiment, the number of Channel Catfish ingested differed among treatments $\left(\mathrm{P}<0.001, \mathrm{~F}_{2,23}=\right.$ 14.43). Most catfish were consumed when small and large fish were available during the trial (Tukey $\mathrm{P}<0.05$ ). Egrets also preferred certain catfish size classes $\left(\mathrm{P}<0.001, \mathrm{~F}_{2,23}=\right.$ 23.82). Egrets preferred small catfish to larger $(15-25 \mathrm{~cm})$ size classes, and more $15-18 \mathrm{~cm}$ catfish were consumed than large fish $(\mathrm{P}<$ 0.05 ; Fig. 3). Thus, egrets preferred small catfish to medium-sized fish, and mediumsized catfish to large fish. Only two large catfish were consumed during this experiment.

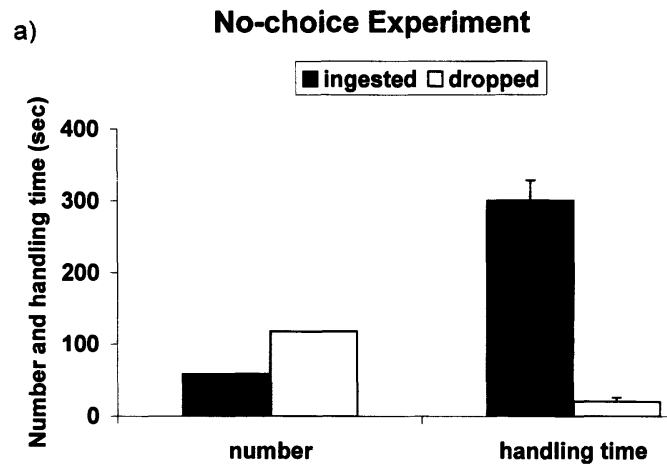

b) Two-choice Experiment

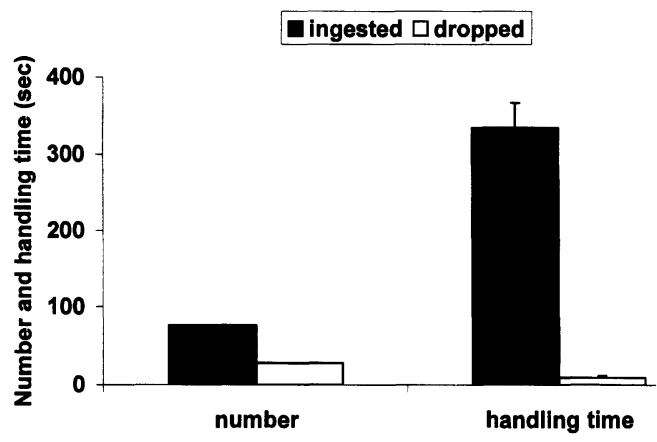

Figure 2. Number of catfish and mean ( \pm SE) handling time (sec.) for catfish ingested, and captured and dropped by 3 captive Great Egrets during the No-Choice Experiment (a) and the Two-Choice Experiment (b).

No significant differences among birds $\left(\mathrm{F}_{2,8}\right.$ $=0.41)$, between trials $\left(\mathrm{F}_{1,23}=1.39\right)$, or in a trial-by-size class interaction $\left(\mathrm{F}_{2,23}=2.08\right)$ were found.

The average handling time associated with each catfish size class again differed in this experiment $\left(\mathrm{P}<0.001, \mathrm{~F}_{2,99}=14.71\right)$. Egrets handled large catfish for more time than smaller fish $(7.5-18 \mathrm{~cm})$, and the handling time of medium-sized catfish was greater than that for small fish $(\mathrm{P}<0.05$; Fig. 3$)$. Egrets ingested nearly three times as many catfish as those that were captured and dropped, and more time was spent handling fish that were ingested $(\mathrm{P}<0.05$; Fig. $2 \mathrm{~b})$. No size class-by-fate interaction was observed in this experiment.

\section{DISCUSSION}

Overnight food deprivation effectively conditioned active foraging by captive Great 

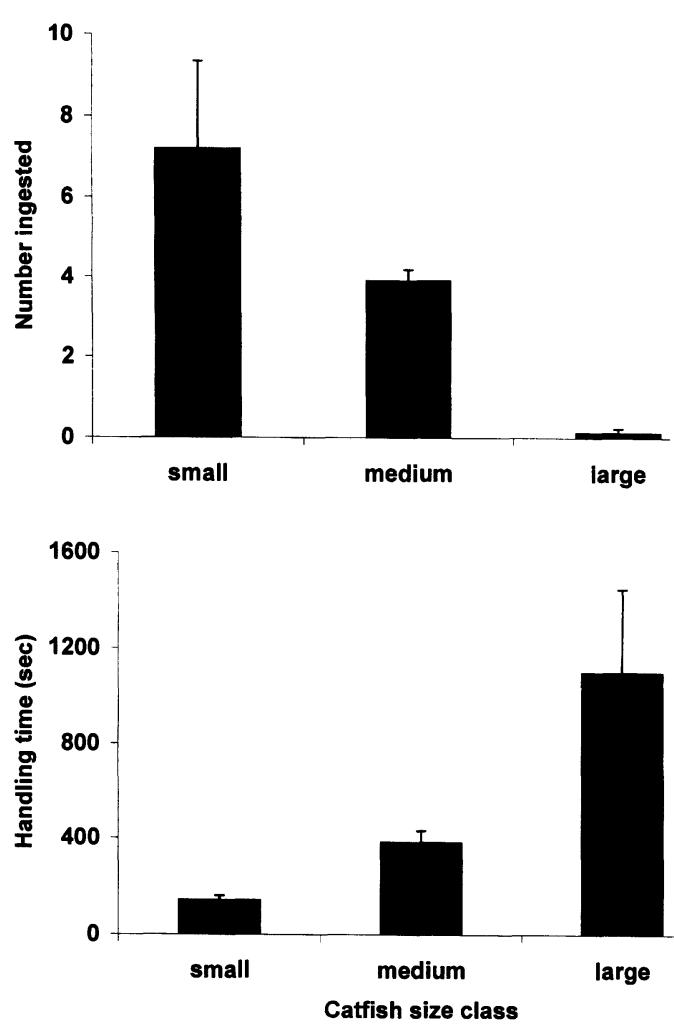

Figure 3. Mean $( \pm S E)$ number of small $(7.5-10 \mathrm{~cm})$, medium $(15-18 \mathrm{~cm})$, and large $(23-25 \mathrm{~cm})$ Channel Catfish consumed by 3 captive Great Egrets when offered two size classes (two-choice) during two replicate foraging trials. The lower half of this figure illustrates the average time $( \pm \mathrm{SE})$ that 3 captive Great Egrets handled catfish during this experiment.

Egrets during the morning foraging trials of this study. When Great Egrets were offered catfish of one length class during foraging trials, we observed them to strongly prefer small catfish fingerlings to larger catfish (15$25 \mathrm{~cm}$; Fig. 1). Considering the relative mass differences among fish length classes, Great Egrets consumed more biomass of mediumsized catfish than small fish during the first (120 versus $64 \mathrm{~g}$, respectively) and second (104 versus $35 \mathrm{~g}$ ) foraging experiments. On average, egrets consumed approximately 25 $\mathrm{g}$ of large catfish during the first experiment and approximately $10 \mathrm{~g}$ of large fish during the second experiment. When given a choice between pairs of three size classes, however, Great Egrets preferred (i.e., consumed more, by number) small to medium catfish, and medium to large fish (Fig. 3).
The results from the present captive study are consistent with field observations near tidal flats and freshwater impoundments (Willard 1977), as well as those on commercial aquaculture facilities in Alabama (Ross 1994). Willard (1977) found that Great Egrets at the Brigantine National Wildlife Refuge in southeastern New Jersey mostly consumed 7.6-10.2 cm fish. Ross (1994) observed Great Egrets consuming cultured catfish that averaged $13.9 \mathrm{~cm}$ in length. Thus, Great Egrets seem to prefer relatively small fish $(<18 \mathrm{~cm})$ in captivity and natural waters, as well as near southern aquaculture facilities.

Handling time was directly related to the size of catfish ingested during both foraging experiments (Figs. 1 and 3). Handling time was inversely related to the number of catfish ingested from each size class, particularly when Great Egrets were given a choice between two catfish size classes (Fig. 3). Thus, factors of handling time (ease of capture, physical defenses) associated with particular foods appear to affect Great Egret foraging preferences. The ingestion of large catfish by Great Egrets may also be limited by the presence of large (pectoral and dorsal) catfish spines.

Since the trial and trial-by-size class factors were insignificant in both foraging studies, Great Egret preference for catfish size classes did not change between trials. Given the same amount of time to forage during all trials of both experiments, Great Egrets were observed to drop twice as many fish as those that were ingested when only one size class was available during the experiment (Fig. 2a). In contrast to the first experiment, however, egrets were observed to ingest nearly three times as many fish as those that were captured and dropped during the Twochoice Experiment (Fig. 2b).

The catfish industry in the United States includes farms designed for the production of catfish fry and fingerlings $(\leq 15 \mathrm{~cm}$ catfish to be cultured in grow-out ponds on the same or other farms), food fish $(0.5-0.7 \mathrm{~kg}$ catfish for human consumption), and brood fish (large catfish maintained for fry production). Food fish are grown from fingerlings on approximately $90-95 \%$ of the acreage as- 
sociated with the southern catfish industry. Techniques used to minimize Great Egret depredation at aquaculture facilities could most efficiently be employed near ponds containing catfish fingerlings and small stockers $(<18 \mathrm{~cm}$ long $)$.

\section{ACKNOWLEDGMENTS}

Brian Dorr and Brent Harrel captured the Great Egrets used in this study. We wish to further thank Brian Dorr, Jim Glahn, and Tommy King for their useful suggestions to earlier drafts of this manuscript.

\section{LITERATURE CITED}

Avery, M. L., D. S. Eiselman, M. K. Young, J. S. Humphrey and D. G. Decker. 1999. Wading bird predation at tropical aquaculture facilities in central Florida. North American Journal of Aquaculture 61: 64-69.

Glahn, J. F., D. S. Reinhold and P. Smith. 1999. Wading bird depredations on Channel Catfish (Ictalurus punctatus) in northwest Mississippi. Journal of the World Aquaculture Society 30: 107-114.

Hoy, M. D. 1994. Depredations by herons and egrets at bait fish farms in Arkansas. Aquaculture Magazine.

King, D. T. and D. LeBlanc. 1995. Foraging behaviors of Snowy Egrets (Egretta thula) and Yellow-crowned Night-Herons (Nyctanassa violacea) in south Louisiana. Colonial Waterbirds 18: 224-225.

King, D. T., J. D. Paulson, D. J. LeBlanc and K. Bruce. 1998. Two capture techniques for American White Pelicans and Great Blue Herons. Colonial Waterbirds 21: 258-260.

Miranda, L. and J. A. Collazo. 1997. Food habits of 4 species of wading birds (Ardeidae) in a tropical mangrove swamp. Colonial Waterbirds 20: 413-418.

Ross, P. G. 1994. Foraging ecology of wading birds at commercial aquaculture facilities in Alabama. Unpublished M.S. thesis, Auburn University.

SAS Institute, Inc. 1989. SAS user's guide, version 6.12. SAS Institute Inc., Cary, NC.

Willard, D. E. 1977. The feeding ecology and behavior of five species of herons in southeastern New Jersey. Condor 79: 462-470.

Young, L. 1998. The importance to Ardeids of the deep bay fish ponds, Hong Kong. Biological Conservation 84: 293-300. 